\title{
JUDICIAL CITATION, THE SUPREME COURT OF CANADA, AND THE LOWER COURTS: THE CASE OF ALBERTA
}

\section{PETER J. McCORMICK}

The author undertakes an examination of the citation practices of the Supreme Court of Canada from 1984 to 1994, with a look at which courts and which judges the Supreme Court tends to favour. Particular attention is given to the frequency of references to the decisions of Alberta courts. Additionally, the article canvasses the basic functions served by the practice of judicial citation.
L'auteur se livre à un examen des pratiques de renvoi de la Cour suprême du Canada de 1984 à 1994, et relève notamment quels sont les tribunaux et les juges qui semblent plus particulièrement avoir les faveurs de la Cour. Il note en particulier la fréquence des références faites aux décisions des tribunaux albertains. De plus, l'article passe en revue les fonctions élémentaires que remplit cette pratique judiciaire.

\section{TABLE OF CONTENTS}

I. THE THEORY $\ldots \ldots \ldots \ldots \ldots \ldots \ldots \ldots \ldots \ldots \ldots . \ldots \ldots 72$

II. THE DATA BASE $\ldots \ldots \ldots \ldots \ldots \ldots \ldots \ldots \ldots \ldots \ldots \ldots . . \ldots 74$

III. THE FINDINGS $\ldots \ldots \ldots \ldots \ldots \ldots \ldots \ldots \ldots \ldots \ldots \ldots$

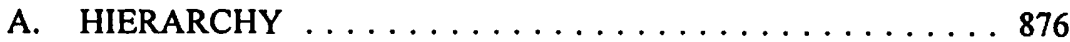

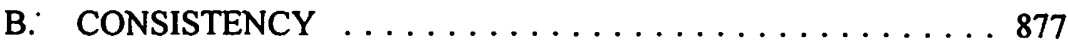

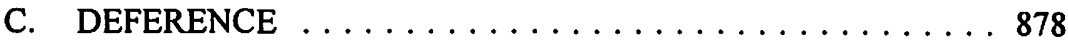

D. CO-ORDINATION $\ldots \ldots \ldots \ldots \ldots \ldots \ldots \ldots \ldots 80$

E. LEADERSHIP $\ldots \ldots \ldots \ldots \ldots \ldots \ldots \ldots \ldots \ldots \ldots \ldots$

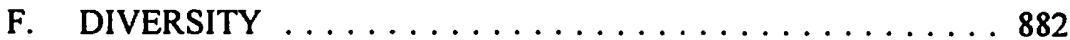

IV. SUPREME COURT CITATIONS TO LOWER

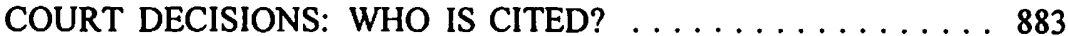

V. SUPREME COURT CITATIONS TO LOWER

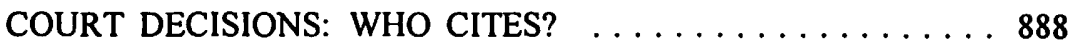

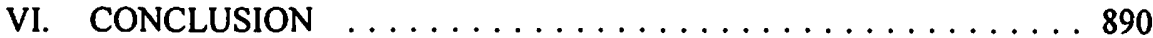

Appeal court judges do not simply deliver decisions but also give reasoned explanations for these decisions,' explanations that usually are organized around citations to judicial authorities. That is to say: judges normally explain why they have chosen a particular outcome in the immediate case by making reference to the decisions

Professor of Political Science, University of Lethbridge. 1 wish to acknowledge the assistance of Madam Justice Hetherington of the Alberta Court of Appeal, who commented extensively on an earlier version of this article.

$1 \quad$ Although this is perhaps less true of trial judges, especially since the Supreme Court decision in $R$. v. Burns, [1994] I S.C.R. 656 at 664, which approved of trial judges "stat[ing] their conclusions in brief compass" and scolded the British Columbia Court of Appeal for being inordinately concerned about "the brevity of the trial judge's reasons." It is interesting to note that this decision would clearly have gone the other way in Australia, where the courts have always recognized a legal obligation for judges (especially when they are sitting without juries) to state clear and complete reasons for their decision. See e.g. Justice M. Kirby, "Ex Tempore Reasons" (1992) 9 Aust. Bar Rev. 93; and for a more extended argument, Justice M. Kirby, "Reasons for Judgment: 'Always Permissible, Usually Desirable and Often Obligatory'" (1994) 12 Aust. Bar Rev. 121. Justice Kirby is a member of the High Court of Australia. 
of other judges and other courts in prior cases. This explanatory style is a characteristic of common law jurisprudence - judges in the continental European tradition, for example, employ a distinctly different explanatory $\operatorname{logic}^{2}-$ and it suggests the possibility that the patterns demonstrated within the citation practices of specific courts can usefully be explored for what they reveal about judicial decision-making. The immediate enquiry will focus on the citation practices of the judges of the Supreme Court of Canada over an eleven-year period, and in particular upon their citation of the lower Canadian courts, especially the courts of the province of Alberta.

Already, this approach to the study of judicial citations requires some explanation. It is normal in the discourse of legal jurisprudence to consider judicial citations in terms of the way that they build toward the reasoned conclusion of a single specific case, ${ }^{3}$ or perhaps more rarely in terms of the way that a single specific case of critical importance is cited in an evolving way over a period of time. ${ }^{4}$ What is proposed here is a somewhat more remote level of analysis, that will similarly accumulate information about cited cases but will do so less in terms of their content and more in terms of their provenance: What courts? Which individual judges? What time periods? Put differently: If the common law is, as it has sometimes been described, a great conversation over time and over distance, then it is useful to know which parts of this conversation are the most listened to. A case (or a judge, or a court) demonstrates some degree of doctrinal influence or importance by the simple fact of being cited; and conversely, the judge who cites an earlier case is pointing other lawyers and judges to an earlier decision that deserves to be considered for its contribution to the development of legal doctrine. $^{s}$

Analysing citation data in this way assumes that the citing judge has some discretion, greater, of course, for some cases than for others, in the sources which are cited to support critical points in the reasoned conclusions, or to establish them with greater certainty, or to locate them in relation to other established legal principles. For any single case, the range of practical choice may be extremely small, although this will still yield information about those judicial sources whose importance is so obvious. Over a sufficiently broad range of cases, in this case, almost fifteen thousand citations in more than one thousand decisions delivered by more than a dozen different judges over an eleven year period, these general patterns will also suggest answers to a number of additional questions of deeper importance. As one example: where is judicial merit situated, in the form of those specific judges on specific courts who contribute disproportionately to the law that is cited by the judges who serve on Canada's highest court? For another: how has the concept of judicial role, in the sense of the mix of courts to which the Supreme Court collectively finds it appropriate to refer, evolved

See e.g. R. David \& J.E.C. Brierly, Major Legal Systems in the World Today, 3d ed. (London:

Stevens \& Sons, 1985), especially Part One, Title III, c. 3.

- Such as the "case comments" or the "recent jurisprudence" sections in journals such as the Canadian Bar Review or the Alberta Law Review.

1 E.g. A. Lokan, "The Rise and Fall of Doctrine Under Section I of the Charter" (1992) 24 Ottawa L. Rev. 163.

s Leaving to one side the relatively infrequent practice of distinguishing a prior decision, and the even rarer practice of explicitly setting aside an earlier case. 
over time? As soon as the citations do not "explain themselves" by the simple fact of their existence, they open the way to an enquiry which will cast light upon other aspects (some more conscious and some more obvious than others) of the decision making process.

\section{THE THEORY}

To begin with the obvious: "Presumably a citation means something to the person citing, and presumably he anticipates that it will have some meaning to a reader." ${ }^{6}$ That is, a judge uses a specific citation for a reason: because of the congruency of factual situation or legal context; or because of the rigour of the doctrinal analysis or the succinctness of its conclusions; or because of the reputation of a specific court or (perhaps more debatably) a specific judge. In the most general terms, a case is cited because it contributes to explaining to the relevant audience (which includes but is by no means limited to the immediate parties) why the outcome is appropriate. Although there are of course important differences, such as the hierarchy of citability implied by the appellate process itself, and the real (although possibly fading) rigour of the doctrine of stare decisis, ${ }^{7}$ this is not in principle fundamentally different from the way that academic articles such as this one organize themselves around references to the relevant literature. $^{8}$

The practice of citation, academic or judicial, serves a triple purpose. Firstly, citations are used to demonstrate a basic knowledge of the relevant subject matter. If one were writing a piece on Canadian federalism, political scientists would expect the bibliography to include the standard articles by people like Alan Cairns and Don Smiley. Similarly, if a judge were to deliver a judgment in a case involving the custodial issues after the break-up of a marriage, judges would expect it to include a reference to the obvious cases like Moge v. Moge, ${ }^{9}$ just as a case on the standards of appellate review would normally make reference to cases like Lensen v. Lensen, ${ }^{10}$ or (for administrative tribunals) to CUPE v. New Brunswick. " As Shapiro suggests, ${ }^{12}$ this constant reiteration serves a double purpose: first, it enhances certainty by making certain sequences or blocks of citation the clearly beaten path of legal doctrine; and second, it highlights error or innovation by making it easy to identify when the standard sequence is broken or altered.

J.H. Merryman, "The Authority of Authority: What the California Supreme Court Cited in $1950^{\prime \prime}$ (1954) 6 Stan. L. Rev. 613.

7 H.P. Glenn, "The Common Law in Canada" (1995) 74 Can. Bar Rev. 261 at 269ff.

\$ I suspect it is also true that academic writers seek to persuade the reader that their's is a plausible approach that contributes to a deeper understanding of a broader topic, while judges seek to convince the reader that their's is the correct resolution of the issuc; this is also an important difference, but not one that undermines the point that is being made here.

[1992] 3 S.C.R. 813.

[1987] 2 S.C.R. 672.

[1979] 2 S.C.R. 227.

M. Shapiro, "Toward a Theory of Stare Decisis" (1972) 1 J. Legal Stud. 125. 
Secondly, citations are used to locate the immediate analysis in the context of established principles and standards. In an academic article, one locates oneself by indicating basic agreement or disagreement, or by suggesting that certain arguments or statements go too far or not far enough. Similarly, judges distinguish past decisions to show how far a legal principle should be extended, or they clarify ambiguities or incompleteness from prior decisions, or they try to resolve apparent (or real) disagreements or divergences within the existing case law, or they try to pull a variety of sources together for an original and creative synthesis. Terrell ${ }^{13}$ has rather fancifully suggested that we can think of each judicial decision as possessing a specific location on a multi-dimensional grid. From this, it follows that the way that the immediate "point" links to an indicated string of prior decisions suggests not just location but also direction, a vector along which the law is developing on a specific point over a period of time. One purpose of citation is to send this line in a desired direction.

Thirdly, citations are used to add weight and credibility to the explanations that are being advanced, making them more convincing and therefore more acceptable to the relevant public. This article has made an argument about the utility of understanding courts by studying their judicial citation patterns; presumably the credibility of this suggestion is enhanced by the fact that it has been made by scholars like Merryman, ${ }^{14}$ Caldeira, ${ }^{15}$ Johnson $^{16}$ and Glenn ${ }^{17}$ in professional journals as distinguished as the Stanford Law Review, the California Law Review, the American Political Science Review, and the Canadian Bar Review. Similarly, a judge enhances the persuasiveness of his reasoning by building it around the comments contained in the decisions of particularly respected courts - and arguably (although this is perhaps a little more debatable) this is all the more true of particularly distinguished judges (Dickson C.J. of the Supreme Court of Canada, Lord Denning of the English Court of Appeal, Learned Hand of the U.S. Federal Court, etc.). This article assumes that there are, to paraphrase White's comment about Justice Holmes ${ }^{18}$ some judges whose opinions carry with them greater authority because of their authorship as well as their content. This factor, which may be operationalized through explicitly naming a cited judge, will be revisited in this article below.

13 T.P. Terrell, "Flatlaw: An Essay on the Dimensions of Legal Reasoning" (1984) 72 Calif. L. Rev. 288.

$14 \quad$ Supra note 6; and J.H. Merryman, "Toward a Theory of Citations: An Empirical Study of the Citation Practice of the California Supreme Court in 1950, 1960 and 1970" (1977) 50 S. Cal. L. Rev. 381.

is G.A. Caldeira, "The Transmission of Legal Precedent" (1985) 79 American Political Science 1978.

16 C.A. Johnson, "Citation to Authority in Supreme Court Opinions" (1985) 7 Law \& Policy 509; and "Follow-up Citations on the U.S. Supreme Court" (1986) 39 Western Political Quarterly 538.

$17 \quad$ Supra note 7.

18 G.E. White, Justice Oliver Wendell Holmes: Law and the Inner Self (New York: Oxford University Press, 1993) at 305. 


\section{THE DATA BASE}

The data base for this analysis was generated by entering every citation to judicial authority made in the decisions, dissents and separate concurrences in every case in the Supreme Court Reports from 1984 to $1994,{ }^{19}$ then looking up each of those citations to identify the cited judge and court. ${ }^{20}$ Attention was limited to citations to judicial authority; although there has been a pronounced tendency in recent years for the Supreme Court to make reference to other sources (such as learned journals or academic texts in this and other countries), these have not been included for present purposes. References to or quotations from statutes (federal, provincial or foreign) have also been omitted.

References to the case immediately under appeal are excluded, on the grounds that this frequency count would be a function less of the Supreme Court's mode of explaining its decision than of the appeal-generating characteristics of the various provinces. To exaggerate a point to make the argument: it is in general terms a characteristic of a strong provincial court of appeal that it is frequently cited by the Supreme Court, but it may well be the sign of a weak court that its own decisions are frequently appealed. ${ }^{21}$ This creates some logical problems, in that it may well be the case that the greatest opportunity for a lower court judge to influence an appeal court is through the appeal process, and the clearest demonstration of that influence is the rejection of the appeal accompanied by a firm and explicit endorsement of the lower court reasoning.2 ${ }^{22}$ On the other hand, appeals may fail even though the lower court's reasoning is rejected ${ }^{23}$ or conversely an appeal may succeed even while the central reasoning is accepted. ${ }^{24}$ Rather than the difficult and judgmental task of deciding

On the inter-provincial variations in appeal frequency, see P. McCormick, "The Supervisory Role of the Supreme Court of Canada: Analysis of Appeals from Provincial Courts of Appeal, 1949-1990" (1992) 3 Supreme Court L.R. (2d) 1.

I wish to indicate our appreciation for the support of the Social Sciences and Humanities Research Council, which funded this project, and for the student research assistants who were involved in the data collection and processing: Charlene Jahnert, Clayton Giles, Stephen Smith, Scott McCormick, Lisa McCormick, Tammy Praskach and David Barva. It is, however, also true that one of the most striking forms of lower court judicial influence would be a Supreme Court decision upholding the appeal court decision and largely echoing its reasons for judgment.

E.g. R. v. Siellato, [1994] 90 C.C.C. (3d) 160. A seven-judge panel of the Supreme Court of Canada dismissed an appeal "for the reasons given by Mr. Justice Labrosse for the Court of Appeal [of Ontario]" in [1993] 78 C.C.C. (3d) 380 . This is surely comparable to the citation of a never appealed decision of a lower court.

See e.g. Black v. Law Society of Alberta, [1989] I S.C.R. 591. The Supreme Court upheld the decision of the Alberta Court of Appeal on the unconstitutionality of the Law Society's regulations on interprovincial firms, but rejected the reasoning based on freedom of association in favor of reasoning based on mobility rights; and in A-G. Quebec v. Protestant School Bds, [1984] 2 S.C.R. 66, the Supreme Court affirmed the Quebec Court of Appeal's finding on the invalidity of the "Quebec Clause" of Bill 101, but rejected the distinction between the "limiting" of a right and the "denial" of a right.

24 See e.g. Stewart v. Pettie, [1995] 177 N.R. 297. The Supreme Court accepted the reasoning of the Alberta Court of Appeal in [1993] 141 A.R. 4; 46 W.A.C. 4, extending the concept of innkeeper's liability, but reversed on the application of that principle to the facts of the immediate case. 
whether or not and to what extent the reasons in the appealed decision exerted some degree of influence on the final outcome, this article will decline to open the can of worms for a simpler if narrower ground, limiting itself to the influence which is demonstrated by the action of citing a judicial authority, without denying or attempting to measure the other ways in which judicial influence may operate.

The eleven years include the closing months of the Laskin Court, all of the Chief Justiceship of Mr. Justice Brian Dickson, and first five years of the Chief Justiceship of Mr. Justice Antonio Lamer. For present purposes, the eleven years will be treated as a single block, rather than using the Chief Justiceships as an axis for comparative analysis. Similarly, with only the most minor of exceptions, the emphasis will be on the citation practices of the Court as a whole rather than on the diverging or exceptional practices of any individual or group within the Court. Nor will there be any differentiation by the type of law, civil or criminal or public or Charter; although there are documented differences in the Court's citation practices relating to each of these areas, the assumption will be that the "mix" of the four types of law has been firmly enough established over the eleven years that it is still reasonable to treat the decisions of each and every judge as contributing to the practices of the Court as a collective whole.

To be sure, a simple count oversimplifies the process of citation by assuming what is clearly not the case: that a citation is a citation and all deserve to be counted equally. On the contrary; some cases are briefly indicated in passing, as single examples of a general point or as one of a string of cases illustrating a trend, while others are considered at length. Some cases are cited approvingly, others criticised or rejected or distinguished; although in practice the citation ratio is heavily in favour of the former. This misleading facade of equality will be penetrated to some extent for the specific category of citations of Alberta courts, but for the early parts of the discussion this counter-factual assumption remains a limitation that qualifies the findings.

\section{THE FINDINGS}

In general, judges cite other judges to explain their decisions for the double purpose of fitting their own ruling into the broader context of law and rendering the outcome more acceptable to the concerned legal public. This being the case, the study of the citation of judicial authorities might usefully be organized around a consideration of the basic values served by the process of judicial citation and by the linkages between specific sets of courts that the practice creates. One might suggest six basic values, and therefore six different types of inter-court relationships implied. This discussion will be linked to the figures in Table 1, identifying the major sources of judicial citations by the Supreme Court of Canada. 
Table 1: Source of Judicial Citations by the Supreme Court of Canada Reported Decisions 1984-1994

\begin{tabular}{|l|c|c|}
\hline Source & Number & Percent \\
\hline Judicial Committee of the Privy Council & 387 & $2.6 \%$ \\
\hline Supreme Court of Canada & 5,763 & $39.3 \%$ \\
\hline Other English Courts & 1,830 & $12.5 \%$ \\
\hline Co-Ordinate Courts & 762 & $5.2 \%$ \\
\hline Lower Canadian Courts & 5,217 & $35.5 \%$ \\
\hline Other Courts & 719 & $4.9 \%$ \\
\hline TOTAL: & 14,678 & $100 \%$ \\
\hline
\end{tabular}

\section{A. HIERARCHY}

The first principle recognized through the practice of judicial citation is hierarchy. The Canadian court system can be diagrammed as a pyramid with the "purely provincial" courts at the base and the Supreme Court of Canada at the apex. For all courts except the Supreme Court this diagram serves to identify the "higher" courts to which the immediate case could theoretically be appealed. Such appeals are statistically infrequent: only about 1 percent of the decisions of any court are actually appealed to the court or courts above it, and sometimes the figure is much lower, but the possibility of such appeal and the hierarchical deference that it generates are an important dimension of the judicial process. It is a valued and central principle of the judicial decision-making of any court that it shape its own decisions around an acceptance of the prior decisions of "higher" courts, although this statement should not be understood in such a way as to deny the intellectual challenges and the creative responses of the lower courts.

For the first seventy-five years of its existence, the Supreme Court of Canada was subject to appeal to the Judicial Committee of the Privy Council in London, the highest court of appeal for Canada as for other political entities that had not shed their connection to the British empire. In 1949, with an amendment to the Supreme Court $A c t,{ }^{25}$ Canada's connection to the Judicial Committee ended, although that "court" continued (and continues) to exist. Only about 250 Supreme Court decisions were ever actually carried to London on appeal, along with a further 400 or so per saltum appeals that went directly from the highest provincial court to the Judicial Committee. ${ }^{26}$ These long constituted binding precedent for the Supreme Court of Canada in the same way 
that its own decisions bound lower (that is to say, all other) Canadian courts. Only in 1978 in Re Agricultural Products Marketing Act, ${ }^{27}$ did the Supreme Court under Chief Justice Laskin explicitly refuse to follow a Privy Council precedent.

Of the total of 14,000-plus citations to judicial authority made by the Supreme Court of Canada in reported decisions over the eleven year period, less than four hundred about one in every forty - were to decisions of the Judicial Committee. This figure includes both Judicial Committee decisions on appeals from countries other than Canada and decisions delivered since 1949, although these enjoy a less binding status than decisions on appeals from Canada itself. Not surprisingly, these low figures are a rather recent development in Supreme Court decision-making; for the Rinfret and Kerwin Courts, references to the Privy Council were about six times as frequent. The waning influence of the Supreme Court's one-time hierarchical superior demonstrates the extent to which the "truly Supreme Court" of the period since 1949 is taking its own independence very seriously.

\section{B. CONSISTENCY}

The second value promoted by judicial citations is consistency. Viewed functionally, one of the purposes of judicial decisions is to promote predictability: to create a regime in which most people most of the time know how their situation will be resolved should a legal dispute arise. This is promoted by a situation in which past decisions of the immediate court have become a normative background into which any specific decision is integrated, which means that a decision (or string of decisions) is valued for its predictive capacity. Reinterpreting or fine-tuning or expanding upon (or sometimes retreating from) the explanations contained in the court's own past decisions is an important part of what the process of judicial decision-making is about.

In Canada, there is considerable confusion about the extent to which an appellate court is bound by its own past decisions. As Gerald Gall has pointed out, ${ }^{28}$ the practices of the ten provincial courts of appeal on this point show such diversity as to defy generalised description. At one time, the Supreme Court of Canada held that it was very much bound to follow its own prior decisions (the critical case is Stuart v. Bank of Montrea $^{29}$ ), but more recently "the Court has gradually come to accept that, while it should normally adhere to its prior decisions, it was not absolutely bound to do so; and the Court has explicitly refused to follow a prior decision in several cases. ${ }^{130}$ It was a hallmark of the early Charter decisions in particular (such as $R$. v. Big $M$ Drug Mart $^{31}$ which ignored Robertson \& Rosetanni v. $R .{ }^{32}$ and $R$. v. Therens ${ }^{33}$ which overturned Chromiak. v. $R^{34}$ ) that the Supreme Court began by declaring that pre-

G. Gall, The Canadian Legal System, 2d ed. (Toronto: Carswell, 1983) at 226-36.

(1909), 41 S.C.R. 516.

P.W. Hogg, Constitutional Law of Canada, 2d ed. (Toronto: Carswell, 1985) at 183.

[1985] I S.C.R. 295.

[1963] S.C.R. 651.

[1985] I S.C.R. 613.

[1980] I S.C.R. 471 
Charter decisions even on very similar points were not necessarily binding in the new judicial world of the Charter. However, whichever side of the "binding precedent" path the Court is inclined to, this still implies the frequent occasion of citations to earlier decisions, either for the purpose of telling lawyers and lower court judges which prior decisions no longer carry weight within the Court, or (much more often) of showing how the current decision fits in with the patterns established in earlier cases.

Among the provincial courts of appeal, citations to their own prior decisions make up one of the largest elements of citation to judicial authority, just fractionally behind the largest category which is comprised of citations to the Supreme Court itself. ${ }^{35}$ Just over one decision in four falls into this category, the proportion being the highest (one third or more) in Quebec and Nova Scotia and the lowest (at or below one sixth) in Manitoba, Prince Edward Island and Newfoundland. This strongly supports the notion that establishing consistency with its own prior decisions is an important element of appeal court decisions, at least in Canada.

References to its own prior decisions similarly loom large within the practices of the Supreme Court of Canada, constituting the largest single bloc among its citations to judicial authority. More than 5,700 citations - just under two-fifths of the total - fall into this category. There are useful clues to the evolution of the way that judicial influence is transmitted and operationalized in the Supreme Court in such questions as which specific Supreme Court cases are cited most often, ${ }^{36}$ and also which individual Supreme Court judges are cited (and named) most often ${ }^{37}$ for present purposes, what is significant is the large but not overwhelming proportion of total citations that they constitute. These figures have been rising over time: for the Rinfret Court, citations to its own earlier decisions made up barely one-fifth of all citations; and for the Kerwin Court (although not after this period) the total number of Supreme Court citations was less than the total number of English citations.

\section{DEFERENCE}

A fourth value promoted through judicial citation is deference, referring in this case to the practice of citing English decisions other than those of the Judicial Committee. English law and English judicial authorities have long been highly regarded and extensively followed in Canada, whether this be regarded as the product of membership in a larger common law community or a residue of Canada's previous colonial and imperial status.

Of course, this suggested dichotomy between Judicial Committee and other English decisions is something of an oversimplification. The Judicial Committee was until 1949 Investigation of Citation Practices" (1993) 22 Man. L.J. 286.

3" P. McCormick, "What Supreme Court Cases Does the Supreme Court Cite?: Follow-up Citations on the Supreme Court of Canada, 1989-1993" (1995) 33 Supreme Court L.R. (2d), forthcoming.

37 P. McCormick, "The Supreme Court Cites the Supreme Court: Follow-Up Citation on the Supreme Court of Canada, 1989-1993" (1995) 33 Osgoode Hall L.J., forthcoming. 
clearly in the position of being a hierarchical superior to the Supreme Court of Canada, given that appeals lay directly from the latter to the former. No other English court could hear an appeal from a decision by a Canadian court. However, the position of the House of Lords remains anomalous. It was from the ranks of the Law Lords that the panel of the Judicial Committee was struck (supplemented from time to time with judges drawn from the highest courts of the Empire/Commonwealth, including the Supreme Court of Canada itself.) And the Judicial Committee itself described the House of Lords as the final authority on questions of English law, ${ }^{38}$ which given Canada's adoption of the English common law, made the Lords an authority for Canadian courts as well. The hierarchy/deference categories turn into a dichotomy what is really a continuum of authority, and this degree of oversimplification must be acknowledged.

References to English cases other than those of the Judicial Committee account for almost two thousand cases over the eleven year period - about one-eighth of the total - which is far more than the numbers for the decisions of the Judicial Committee itself, but less frequent than either citations of prior decisions of the Supreme Court or (perhaps surprisingly) citations to lower Canadian courts. A similar study ${ }^{39}$ of the citation practices of the provincial courts of appeal reveals that these courts cited British sources (and the Judicial Committee) comparably often. The extent to which this is a characteristic of the Canadian judiciary, rather than of the common law itself, is shown by comparison with the practices of U.S. courts, where citations to English authority are extremely rare. ${ }^{40}$

The decline in the relative frequency of English citations has been steady. In the 1940s, British courts other than the Judicial Committee were supplying four of every ten citations to judicial authority made by the Supreme Court of Canada; adding in the Judicial Committee cites pushes the figure closer to six of every ten. By 1994, considering this single year on its own, this figure had plummeted to one in every sixteen (about one in fourteen if Judicial Committee references are included.) The English courts remain a significant source of precedent for Supreme Court decisions, even within the area of criminal law, but they are no longer dominant. To this extent, the "captive court" of which Professor Bora Laskin, as he then was, complained so long ago, ${ }^{41}$ has come to an end. The hopes of those who saw the termination of appeals beyond the Supreme Court as a new and important starting point have been fulfilled.

The critical case is Robins v. National Trust Co., [1927] A.C. 515. See also Hogg, supra note 30 and accompanying text.

Comments based on research in progress. Some of the findings of this project have been reported in McCormick, supra note 35.

J.H. Merryman, "Toward a Theory of Citations" (1977) 50 S. Cal. L. Rev. 381 at 400, and

L.M. Friedman, "State Supreme Courts: A Century of Style and Citation" (1981) 33 Stanford

L. Rev. 773 at $798-99$.

B. Laskin, "The Supreme Court of Canada: A Final Court of and for Canadians" (1951) 29

Can. Bar Rev. 1038. 


\section{CO-ORDINATION}

A fourth function of judicial citation is co-ordination, using this term to pick up on what Ross Flowers has called "co-ordinate citation":42 references to the decisions of courts that are neither above nor below the citing court in any judicial hierarchy, but which occupy a similar position within their own judicial hierarchy. Strictly speaking, Flowers' reference is to courts that occupy a similar position in the sense of both being subject to appeal to the same higher authority. In this restricted sense, the only citations that would qualify would be pre-1949 references to the courts of other countries that were similarly subject to appeal to the Judicial Committee; that is, the highest courts of other countries within the Empire/Commonwealth such as Australia or New Zealand. In this narrow sense, the Supreme Court has done little in the way of coordinate citation.

However, it may be defensible to use the term in a more expanded sense. Now that the Supreme Court of Canada is supreme in fact as well as in name, parallel authorities would be those similarly located at the top of a pyramid of judicial review within a federal or quasi-federal setting; the Supreme Court of the United States, or the Australian High Court, or (more recently and perhaps a little more dubiously) the European Court of Justice ${ }^{43}$ or the European Court of Human Rights. Only the first named is measurably common; the coordinate citations in Table 1 include 625 references to the Supreme Court of the United States, ninety-two to the Australian High Court, and forty-five references to the highest European Court (almost all to the European Court of Human Rights rather than the European Court of Justice). Together, these account for barely one citation in every twenty. As one way to make the point: right up until the most recent decade, the Supreme Court of Canada has been more likely to cite the Judicial Committee of the Privy Council than the United States Supreme Court, and this remains the case even if citations of the Australian High Court are thrown into the balance as well. Given that the United States and Australia constitute the two federal common law systems in the world most similar to the Canadian, this fact is striking. However, it should be noted that this frequency is increasing from even lower levels on earlier Courts. Altogether, the previous forty years of reported Supreme Court decisions include less than 200 references to the US Supreme Court and less than 100 to the Australian High Court.

By contrast, the practice of co-ordinate citation on the part of the provincial courts of appeal is well-established and longstanding. Not only is the number reasonably large, about one citation in every six in recent decades, but the patterns of interprovincial citation are sufficiently persistent and striking that they can be more closely 464.

" On the recent emergence of the European Court of Justice as a court of last review, see e.g. J.H.H. Weiler, "A Quiet Revolution: The European Court of Justice and Its Interlocutors" (1994) 26 Comparative Political Studies 510; and A-M. Burley \& W. Mattli, "Europe Before the Court: A Political Theory of Legal Integration" (1993) 47 International Organization 41. 
analysed. ${ }^{44}$ As against its provincial counterparts, the Supreme Court draws from a precedential pool that is less diversified, more concentrated on a relatively small number of sources, including primarily its own prior citations. However, it should be noted that with the possible and somewhat sporadic exception of the Ontario Court of Appeal, the provincial appeal courts do not make much use of American case law either.

\section{E. LEADERSHIP}

The fifth value served by the practice of judicial citation is that of judicial leadership, exemplified by Supreme Court citations of lower courts (which by definition, given that the Supreme Court of Canada is the "general court of appeal" contemplated in s. 101 of the Constitution Act 1867, means all other Canadian courts). In such citations, the Court is arguably less concerned to fit its own decision in with the practices of these courts than to accomplish the reverse: to show the lower courts which statements of law and doctrine do, and do not, mesh with the views of the Supreme Court of Canada. To some extent this is done directly by upholding or reversing or altering the immediate case under appeal, and the question of which provincial courts are reversed how often is itself of some interest, ${ }^{45}$ but this study has explicitly excluded the immediate case under appeal from the citation data base.

The immediate case aside, the Supreme Court may explicitly refer to the decisions of that and other provincial or federal courts in the process of explaining its decision. In the process of commenting on these cases, it may endorse or reject or modify or distinguish the statements of law and doctrine enunciated by these lower courts. Indeed, an important part of the function of a general court of appeal lies in its capacity to take advantage of its one-further-step removal from the immediacy of the trial situation, as well as the diversity of context and fact situations that may have emerged in a broad range of trial courts and been considered by several appeal courts, to present a running synthesis of Canadian legal doctrine on new or maturing legal issues.

With 5,217 citations, just over one-third of the total, references to the decisions of the lower courts ranks second in Supreme Court citation patterns only to the prior decisions of the Supreme Court itself. This has been a persisting pattern: citations to "lower" Canadian courts accounted for almost one-fifth of the citations of the Rinfret Court as well. Although this component of citation has been characterized as exhibiting judicial leadership, it would be misleading to think of this as entirely a one-way street. Certainly very strong judges have served on the various courts of appeal, and given the accidents of timing and regional representation that surround the appointment process, it is on the face of it unlikely that the nine judges on the Supreme Court have always been the nine best judges in the country. Justice Learned Hand of the Federal Circuit Court is sometimes referred to as the finest judge never to serve on the United States 
Supreme Court, ${ }^{46}$ a clear implication being that he has made a larger contribution to the law than some of the lesser lights who cleared this last hurdle. ${ }^{47}$ Ontario's Justice Martin of the Court of Appeal may well be the leading example of his Canadian counterparts.

\section{F. DIVERSITY}

The sixth value that is served by judicial citations is diversity. If the underlying principle of the common law is that law is discovered not made, then it can be discovered not just within the courts of the immediate judicial hierarchy but literally anywhere. The range of sources theoretically available to the Canadian judge is truly overwhelming; not just in the decisions of Canadian courts and English courts, but also in the case law of the courts of the Anglo-American judicial systems inside and outside the Commonwealth, where judges apply the logical processes of the common law to a wide range of modern social and legal problems. The fact that the Supreme Court of Canada also hears appeals from the civil law system of Quebec opens up another range of sources potentially relevant to the case at hand, in the form of the jurisprudence of the civil law countries of continental Europe. Glenn suggests that this creative openness to a wide range of sources is one reason why the civil law decisions of the Supreme Court are well received in Quebec. ${ }^{48}$

As a number of sources ${ }^{49}$ have pointed out, there has in recent years been a dramatic increase in the activity and the visibility of national and supra-national courts in many parts of the world, making it more credible than ever before to treat these operations as potentially parallel to the activities of the Supreme Court and other Canadian courts. This emerging globalization of judicial power may prove to be one of the most important developments of the late twentieth century, and the willingness to tap these newer sources of jurisprudence is an important dimension of Supreme Court decision-making (although much less so of provincial appeal court decisionmaking) in recent years.

During the eleven year period considered, the Supreme Court made just over 700 citations to sources that could not be brought under any of the five categories above. Most of these were citations to U.S. courts other than the U.S. Supreme Court, accounting for 539 citations that were divided roughly equally between the federal

46

See e.g. G. Gunther, Learned Hand: The Man and the Judge (New York: Alfred A. Knopf, 1994).

47 See e.g. D.P. Currie, "The Most Insignificant Justice: A Preliminary Inquiry" (1983) $50 \mathrm{U}$. Chicago L. Rev. 466; and F.H. Easterbrook, "The Most Insignificant Justice: Further Evidence" (1983) U. Chicago L. Rev. 481.

48 Supra note 7 at 289: "The Supreme Court's expansive view of civil law authority has in recent years greatly contributed to the reception its decisions have received in Quebec."

4 See e.g. C.N. Take \& T. Vallinder, eds., The Global Expansion of Judicial Power (New York: New York University Press, 1995). See also the special issues of (1994) 26 Comparative Political Studies and (1992) 15 West European Politics were dedicated to the recent emergence of judicial power in Europe and elsewhere, the latter being reprinted in book form as M.L. Volcansek, ed., Judicial Politics and Policymaking in Western Europe (London: Frank Cass \& Co., 1992). 
circuit and appeal courts and a wide range of state courts. It should be noted in passing that this is the first decade for which the number of United States Supreme Court cites exceeded the number of U.S. lower court cites; to the extent that the Supreme Court of Canada has in the past drawn on U.S. law ${ }^{50}$ this has been less the law of the Supreme Court than that of the state and federal courts.

There were also more than 100 citations to the lower courts of various commonwealth countries, mostly Australia and New Zealand but with scattered references to Ireland, South Africa, India and Hong Kong. These too have been a continuing source at a comparably modest level for decades. References to European courts (other than the European Court of Justice or the European Court of Human Rights) accounted for a total of sixty-two citations; although European references have figured sporadically in the earlier jurisprudence of the Supreme Court, it is only recently that there were any significant number of references to any European courts other than those of France. Finally, there were almost a dozen "other" citations - half to Israeli courts, and half to the decisions of the post-World War II International War Crimes Tribunal.

These diversity citations account for only one citation in twenty by the Supreme Court of Canada, a modest figure that has grown only slightly over earlier decades although it is more pronounced if "foreign" law is taken to include the category of coordinate citation above. ${ }^{51}$ The use of foreign authority is clearly an example of what Glenn has referred to as the "open view of the common law," significant indication of the evolution of the judicial role in Canada even if the actual citation frequencies are not high.

\section{SUPREME COURT CITATIONS TO LOWER COURT DECISIONS: WHO IS CITED?}

During the decade beginning in 1984, the Supreme Court of Canada made 4590 citations of provincial court decisions, this comprising just over 30 percent of all judicial citations. For present purposes, this omits the citations of the federal trial and appeal courts, and also of a variety of federal and provincial boards: labour arbitration, labour relations, workers compensation and immigration appeal boards. This explains the difference between the figure of 5217 in Table 1 and the 4590 in this section. Of these, only a small fraction (about 2 percent) were to the decisions of the "purely provincial" courts at the bottom of the Canadian judicial hierarchy; roughly two thirds of the references were to decisions of the provincial courts of appeal, and one-third to the s. 96 trial courts. Table 2 breaks this data down by province and by court level. The

See e.g. J.M. Macintyre, "The Use of American Cases in Canadian Courts" (1966) 2 U.B.C. L. Rev. 478; and S.I. Bushnell, "The Use of American Cases" (1986) 35 U.N.B.L.J. 157.

Glenn, supra note 7 at 288 which indicates that the absolute number of references to foreign law have more than doubled since the 1950 s and now account for a full third of all citations; this should be qualified by noting that the absolute number of judicial citations per decision has itself increased dramatically, and that the conclusion depends on including English law as part of "foreign" law, a description which would make many judges uncomfortable.

Ibid. 
territorial row is included for reasons of logical completeness; the territorial appeal courts are of course comprised of judges drawn largely from the provincial appeal courts of the western provinces - the British Columbia Court of Appeal for the Yukon, and the Courts of Appeal of Alberta and Saskatchewan for the North West Territories. Strictly speaking, their highest trial court cannot be a s. 96 court because the territories are not provinces.

The general ratio of two appeal court cites for every trial cite seems to hold true for all the provinces except two. Prince Edward Island is the only province to have received more trial court cites than appeal court (or trial court en banc) cites; this is probably a function both of the small number of citations involved, and of the recent creation of the full-time specialized appeal court in $1987 .{ }^{53}$ New Brunswick, on the other hand, has the highest such ratio at $4: 1$.

Table 2: Frequency of Citation of Lower Courts, by Province and Level Supreme Court Decisions 1984 - 1993

\begin{tabular}{|c|c|c|c|}
\hline & $\begin{array}{c}\text { Court } \\
\text { of Appeal } \\
\text { s4 }\end{array}$ & $\begin{array}{c}\text { Other s. } 96 \\
\text { courts }^{55}\end{array}$ & $\begin{array}{l}\text { Provincial } \\
\text { Courts }\end{array}$ \\
\hline British Columbia & 439 & 257 & 13 \\
\hline Alberta & 216 & 135 & 5 \\
\hline Saskatchewan & 141 & 74 & 12 \\
\hline Manitoba & 175 & 85 & 6 \\
\hline Ontario & 1130 & 554 & 31 \\
\hline Quebec & 546 & 265 & 40 \\
\hline Prince Edward Island & 15 & 26 & 0 \\
\hline New Brunswick & 101 & 26 & 4 \\
\hline Nova Scotia & 133 & 77 & $\dot{3}$ \\
\hline Newfoundland & 24 & 16 & 5 \\
\hline Territories & 22 & 14 & 0 \\
\hline TOTAL: & 2942 & 1529 & 119 \\
\hline
\end{tabular}

See P.H. Russell, The Judiciary in Canada: The Third Branch of Government (Toronto: McGrawHill Ryerson, 1987) at 291.

s4 Includes s. 96 trial court sitting en banc, for those years in which a province did not yet have a full-time specialized court of appeal; there were sixteen such cases cited.

ss Includes decisions by the Ontario Divisional Court and by the Quebec Cour Superieur en revision. both representing s. 96 panel courts "lower" than the Court of Appeal, but "higher" than the regular $\mathrm{s} .96$ trial court. 
Overall, there seems to be something close to a 4:4:2:1 ratio that applies to appeal and trial citations as well as to the overall totals: in every eleven citations of provincial court decisions, there are about four references to Ontario courts, four to Western courts, two to Quebec courts, and one to the courts of the four Atlantic provinces. This roughly replicates the patterns that emerged from the study of interprovincial citations, ${ }^{56}$ although the predominance of Ontario over the West is less pronounced in the Supreme Court than in the provincial courts of appeal. As was suggested in that study, the lower figures for Quebec are probably the consequence of the double isolation of civil code and French language, and the low numbers for the Atlantic provinces are explained by both the relatively recent creation of the specialized appeal courts and their comparatively low caseload.

Obviously, some judges are cited more often than others, and this information is gathered in Table 3. Specifically there are almost three dozen judges of the various provincial courts who have been cited by the Supreme Court of Canada at least twenty times over the eleven years considered here. The individual judge who particularly stands out is Mr. Justice Martin of the Ontario Court of Appeal, who was cited about four times as often as any other single judge; indeed, this one individual was cited more often than most courts. One member of the Alberta Court of Appeal, Mr. Justice Kerans, ranks among the ten most frequently cited judges in Canada with thirty-six citations; and a second, former Chief Justice Laycraft, finished just off the list with nineteen. There were only two judges, both from the Ontario High Court, who were cited twenty times or more without having served on a provincial court of appeal. Alberta's Justice D.C. McDonald of the Court of Queen's Bench ${ }^{57}$ fell just short of this list with seventeen, making him one of the three most frequently cited trial judges in the country. Ontario judges clearly dominate the citation frequency table, with eighteen of the thirty-three most cited judges, including seven of the top ten. British Columbia has five judges on the list, Nova Scotia four, and Manitoba three. The fact that only there is only a single Quebec judge is really a product of the incompleteness of the data base owing to the difficulty of access to Quebec law reports; these lists should really be thought of as providing information only about the nine Englishspeaking provinces. 
Table 3: Most Frequently Cited Provincial Court Judges

Supreme Court Citations in Reported Cases, 1984 S.C.R. through 1994 S.C.R.

\begin{tabular}{|c|c|c|}
\hline Judge & Court & $\begin{array}{l}\text { Times } \\
\text { Cited }\end{array}$ \\
\hline Martin & Ont. C.A. & 219 \\
\hline Dubin* & Ont. C.A. & 58 \\
\hline Morden & Ont. H.C. \& C.A. & 52 \\
\hline Macfarlane & B.C.C.A. & 50 \\
\hline Lacourciere & Ont. H.C. \& C.A.. & 42 \\
\hline Cory & Ont. C.A. & 42 \\
\hline Mackinnon & Ont. C.A. & 41 \\
\hline Brooke & Ont. C.A. & 40 \\
\hline Macdonald & N.S.C.A. & 38 \\
\hline Kerans & Alta Dist., Q.B. \& C.A. & 36 \\
\hline Nemetz* & B.C. S.C. \& C.A. & 34 \\
\hline Anderson & B.C. S.C. \& C.A. & 30 \\
\hline Goodman & Ont. H.C. \& C.A. & 30 \\
\hline Lambert & B.C.C.A. & 29 \\
\hline Laidlaw & Ont. C.A. & 29 \\
\hline Arnup & Ont. C.A. & 27 \\
\hline Zuber & Ont. C.A. & 27 \\
\hline Monnin* & Man. Q.B. \& C.A. & 26 \\
\hline Culliton* & Sask. C.A. & 24 \\
\hline Turgeon & Que. C.A. & 24 \\
\hline Schroeder & Ont. C.A. & 24 \\
\hline Middleton & Ont. H.C. \& C.A. & 24 \\
\hline Huband & Man. C.A. & 22 \\
\hline Jones & N.S.C.A. & 22 \\
\hline MacKeigan & N.S.C.A. & 21 \\
\hline Craig & B.C. S.C. \& C.A. & 21 \\
\hline Howland* & Ont. C.A. & 20 \\
\hline Tarnopolsky & Ont. C.A. & 20 \\
\hline Linden & Ont. H.C. & 20 \\
\hline Hall & Man. Q.B. \& C.A. & 20 \\
\hline Hart & N.S. C.A. & 20 \\
\hline Galligan & Ont. H.C. \& Div. Ct. & 20 \\
\hline Jessup & Ont. H.C. \& C.A. & 20 \\
\hline
\end{tabular}

Sometimes, but not all the time or even most of the time, the citing judge will specifically name the cited judge. For citations of lower Canadian courts, this is the case 32.3 percent of the time. By way of comparison, citations of earlier Supreme Court decisions include such an explicit identification just under one half of the time, and the patterns of specific naming are sufficiently consistent and logical to bear further 
examination. ${ }^{58}$ References to the provincial courts of appeal include specific names 35 percent of the time, to the s. 96 trial courts 30 percent of the time, and to the provincial courts less than 25 percent of the time, a business-like descending scale that neatly reflects the judicial hierarchy (and all the more so when it is combined with the 50 percent for references to the Supreme Court itself). Among the appeal courts, the Manitoba Court of Appeal is the one most likely to be named as well as cited (41.0 percent of the time), about twice the figure for the New Brunswick Court of Appeal (22.3 percent).

Since the choice of whether or not to name the judge in a cited decision is presumably a logical one on the part of the citing judge, and since it results in a specific name being supplied only about one third of the time, it seems reasonable to assume that the emphasis has a purpose and this purpose links to the judge being named. Again to use White's phrase: presumably there are some judges whose decisions are more highly regarded because they are their's. More bluntly, it may well be the case that the practice of naming identifies the most highly regarded of the lower court judges, the more so as citations are almost never accompanied by negative comment.

To the extent that this argument is persuasive, the most outstanding judge identified is Mr. Justice Martin of the Ontario Court of Appeal, who was named 115 times. It is a measure of his predominance that there was a three way tie for runner-up (Dubin C.J. Ontario; Morden J.A. Ontario; Anderson J. \& J.A. British Columbia) with nineteen named citations each; indeed, Martin was named as often as the next seven judges combined. In all, twenty judges were explicitly named in citations more than ten times (that is, at least once a year on average over the eleven years considered). In addition to the four already indicated, they included Brooke, Cory, Laidlaw, Laskin, Lacourciere, Schroeder and Zuber JJ.A. and Mackinnon A.C.J. of the Ontario Court of Appeal, Monnin C.J. from the Manitoba Court of Appeal, Linden and Borins JJ. of the Ontario High Court, Lambert and Macfarlane JJ.A. from British Columbia, Macdonald J.A. from the Nova Scotia Court of Appeal, Mayrand J.A. from the Quebec Court of Appeal, and Kerans J.A. from Alberta. Apart from the obvious and overwhelming emphasis on Ontario, the most obvious thing about the list is that only two of the eleven were Chief Justices.

To be sure, neither Table 3 nor the list in the paragraph above can be taken in any simple sense as an indication of merit (although neither is it reasonable to suggest that merit is irrelevant to the appearance of names on the lists). Judicial ability seems to be passed through a triple filter, these being length of judicial service, recency of judicial service, and whether or not the individual served on an Ontario court. That said, the two lists do in some sense indicate the two or three dozen judges on the provincial courts who exhibit the greatest influence on the Supreme Court of Canada, to the extent that frequency of judicial citation is a reasonable indication of this influence. 


\section{SUPREME COURT CITATIONS TO LOWER COURT DECISIONS: WHO CITES?}

If one side of the equation is "who is cited?" the other is "who does the citing?" One possibility, all the more plausible because most (if recent practice is hardening into convention, seven of the nine) judges of the Supreme Court of Canada are normally elevated from the provincial courts of appeal, is that they carry with them both a familiarity with their own court's (and more generally their own province's) jurisprudence and a readiness to incorporate this into their reasons for judgment on the Supreme Court. If this were the case, then one would expect something of a "homer" effect: within their citations of lower court decisions, Supreme Court judges would be more likely to emphasize their home province. In order to highlight systemic tendencies over purely individual styles, Table 4 presents this data in terms of a double consolidation: first, the cited cases are accumulated not on a purely provincial basis but rather on the basis of the four regions (Atlantic, Quebec, Ontario, West) which by law or by convention constrain appointments to the Supreme Court; and secondly, the totals for the Supreme Court judges who are doing the citing are similarly aggregated by region.

Table 4 indicates that there is in fact no generalisable "homer" effect. Judges from Ontario, from the West, and from the Atlantic provinces are virtually indistinguishable in the way they draw their citations from the various provincial courts: all cite Ontario courts most often, Western courts slightly less often, and Atlantic courts about onequarter as often. At first glance, it seems striking that Atlantic judges are less likely than Western or Ontario judges to cite Atlantic courts and more likely to cite Quebec courts, although it is important to remember that we are talking here about a single individual who has filled the Atlantic seat on the court for almost all of the decade.

Table 4: Citations of Lower Court Cases, by Province of Judge and Province of Cited Case Reported Supreme Court Decisions, 1984-1994

\begin{tabular}{|l|c|c|c|c|}
\hline & Western Courts & Ontario Courts & Quebec Courts & Atlantic Courts \\
\hline Western Judges & $41.6 \%$ & $41.4 \%$ & $5.1 \%$ & $11.9 \%$ \\
\hline Ontario Judges & $39.1 \%$ & $43.7 \%$ & $5.4 \%$ & $11.9 \%$ \\
\hline Quebec Judges & $24.6 \%$ & $27.4 \%$ & $41.9 \%$ & $6.1 \%$ \\
\hline Atlantic Judges & $41.5 \%$ & $41.9 \%$ & $9.2 \%$ & $7.4 \%$ \\
\hline ALL JUDGES & $34.5 \%$ & $37.1 \%$ & $19.1 \%$ & $9.3 \%$ \\
\hline
\end{tabular}

The important exception, however, in this as in so many things, is Quebec. Supreme Court judges from Quebec are about eight times as likely as their colleagues from English Canada to draw references from Quebec decisions. As a consequence, they are less likely to draw references from courts in each of the other three regions: although the Ontario/West/Atlantic ratios in the references they do use is very similar to that of 
all other judges. This Quebec-centred pattern is doubly understandable in terms both the language question and the personal background and experience of the Quebec judges; the Civil Code question is probably not particularly relevant, as so few civil law cases have been reaching the Supreme Court in the last decade. ${ }^{59}$

Citations to decisions of Alberta courts account for 7.75 percent of all Supreme Court citations of lower court decisions. The heaviest consumers of Alberta court citations were Dickson C.J. and Wilson $J$. (both in absolute numbers and as a percentage of all provincial court citations); Estey J. and Iacobucci J. also use Alberta citations more often than average, although their total numbers are significantly lower. Stevenson J. and Major J., the two Alberta judges who recently served on the Supreme Court, also tend to cite Alberta cases frequently - in Major's case, very frequently but for both of them the time of service is too brief and the total number of provincial court citations too small to permit confident generalization.

The 356 citations identified 295 different Alberta decisions, only one of which the decision of Kerans J.A. in Black v. Law Society of Alberta ${ }^{60}$ - was cited as often as four times. Ten other appeal court decisions (two per curiam decisions, and five by five different members of the Court) were cited as often as three times, as was a single decision ${ }^{61}$ by Mr. Justice Shannon of the Court of Queen's Bench. Another twenty-six appeal court decisions and fifteen Queen's Bench or Trial Division decisions were cited twice. Exactly half (twenty-five of fifty) of these more frequently cited decisions were criminal cases. The citations to Alberta decisions involved eighty-seven different appeal court judges, forty-four of whom were specifically named at least once. Only seventeen were cited as often as six times, and twelve were cited eight times or more. These higher frequencies are specifically identified in Table 5.

Table 5: Frequency with which Alberta Judges were cited Supreme Court Decisions 1984-1993

\begin{tabular}{|l|c|c|}
\hline Judge & Times Cited & Times Named \\
\hline Kerans J.A.* & 36 & 13 \\
\hline Laycraft C.J.* & 19 & 9 \\
\hline McDonald J. & 17 & 7 \\
\hline McClung J.A.* & 16 & 2 \\
\hline
\end{tabular}

J.L. Baudoin, "Chronique de Droit Civil Quebecois: Session 1985-1986" (1987) 9 Supreme Court L.R. 319. See also J.L. Baudoin, "Chronique de Droit Civil Quebecois: Session 1986-1987" (1988 10 Supreme Court L.R. 175. Both articles limit themselves to discussing a single case. More recently, C. Masse, "Chronique de Droit Civil Quebecois: Session 1988-89" (1990) I Supreme Court L.R. (2d) 325, with six cases to discuss, begins by commenting on the unusual proliferation of cases and issues. 


\begin{tabular}{|l|c|c|}
\hline Judge & Times Cited & Times Named \\
\hline Sinclair C.J. \& J.A. & 15 & 5 \\
\hline Clement J.A. & 13 & 6 \\
\hline Stevenson J.A. & 10 & 4 \\
\hline Ford J.A. & 9 & 3 \\
\hline Harradence J.A. & 8 & 4 \\
\hline McGillivray C.J. & 8 & 3 \\
\hline Moir J.A. & 8 & 2 \\
\hline Stuart J.A. & 8 & 0 \\
\hline
\end{tabular}

Note: * includes citations for decisions made as N.W.T. C.A.

\section{CONCLUSION}

As is the case with other courts in the Anglo-American world, the Supreme Court's weapon of choice in the persuasive arsenal is citations to judicial authority. These citations are drawn from a range of sources, although the heavy reliance on British authorities is increasingly a thing of the past, having been replaced by a tendency for the Supreme Court to cite its own prior decisions. Citations from the courts of other countries, even other federal countries such as the United States and Australia, are relatively rare.

About one-quarter (in recent years it is closer to one-third) of all citations are to the decisions of the lower Canadian courts, the bulk of these coming from the various provincial appeal courts. Other studies ${ }^{62}$ have described the relationship of the provincial courts to the Supreme Court of Canada primarily in terms of appeal frequency and reversal rates, a strong court being one that is reversed infrequently, and on this approach Ontario easily tops the list while Quebec trails surprisingly. This study suggests an alternative relationship in terms of citation frequency, which maintains Ontario's predominance but has the consequence of restoring the Quebec Court to a position of greater prominence.

The Alberta courts are neither unusually visible nor unusually invisible in the citation practices of the Supreme Court of Canada, Alberta ranks fourth in citation frequency, well behind British Columbia but well ahead of Manitoba. This is roughly what the 
province's share of the national population and of the total of appeal court judges would suggest to be appropriate. The citation tables are dominated by the longerserving judges of the recent courts of appeal, a tendency sufficiently obvious as to explain itself, although the strong presence of a s. 96 trial judge is also striking.

Some of these citations of Canada's lower court cases constitute an indirect way of over-ruling a lower court decision that may not have been appealed, specifically identifying an error or an inappropriate way of resolving a particular issue, but these are a very small minority. Others involve the Supreme Court identifying two or more general lines of interpretation emerging in the practices of the lower courts, and then choosing (or creating) a single national doctrine to replace this diversity. More typically, however, these lower court citations are treated the same way as self-citations or invocations of the English authorities; that is, they are taken as confirmations of legal doctrine or as sources of legal ideas deserving consideration in their own right. Some lower court judges think of the judicial pyramid less as a strict hierarchy in which error flows upward to be corrected and truth flows down to be followed, than as a conversation (albeit something less than a conversation of equals) between higher courts and lower courts. ${ }^{63}$ The way in which the Supreme Court treats many of these citations of lower court decisions strongly suggests that this conversational mode is an appropriate description.

As Glenn has noted in a different context, ${ }^{64}$ this study of Supreme Court citation patterns suggests a reliance on a diversity of sources, and an approach to lower court cases which is as likely to be collegial as admonitory. This being the case, the diffusion of specific ideas from the courts of one province to the courts of other provinces and possibly to the Supreme Court itself presents itself as an area that might usefully be explored, although this is beyond the scope of the present study. 